\section{Leafminer Resistance in Lettuce}

\author{
Beiquan Mou' ${ }^{1}$ and Yong-Biao Liu $^{2}$ \\ U.S. Dept. of Agriculture, Agricultural Research Service, 1636 East Alisal \\ Street, Salinas, CA 93905
}

\begin{abstract}
Additional index words. Liriomyza langei, Liriomyza huidobrensis, insect resistance, heritability, Lactuca sativa, Lactuca serriola, Lactuca saligna, Lactuca virosa
\end{abstract}

\begin{abstract}
Leafminer (Liriomyza langei Frick) is a major insect pest of many important agricultural crops including lettuce (Lactuca sativa $\mathbf{L}$.). The goals of this study were to evaluate lettuce genotypes for resistance to leafminer and to estimate heritabilities of three leafminer-resistant traits. Forty-six lettuce genotypes were evaluated in two tests in insect cages. Wild species (Lactuca serriola $\mathbf{L}$., Lactuca saligna $\mathrm{L}$., and Lactuca virosa $\mathrm{L}$.) had significantly fewer leafminer stings than cultivated lettuce (L. sativa) in both tests. PI 509525 (L. saligna) had few leafminer stings and no flies emerged. Leaf (leaf and romaine) lettuce also showed significantly less stings than head (crisphead and butterhead) types, while differences between leaf and romaine lettuces, and between crisphead and butterhead types were nonsignificant. Broad-sense heritability for number of stings per unit leaf area was relatively high, averaging $65 \%$ over the two tests. Heritabilities for egg-hatching period and flies per plant were $10 \%$ and $15 \%$, respectively. Stings per unit leaf area from the two tests were highly correlated $(r=0.828)$, suggesting that resistance was stable over different plant ages and against different pressures of leafminer. These results suggest that genetic improvement of cultivated lettuce for leafminer resistance is feasible.
\end{abstract}

Leafminers are major insect pests of many important agricultural crops (Parrella, 1987). The principal leafminer species affecting vegetables include Liriomyza brassicae, L. sativae Blanchard, L. trifolii (Burgess), $L$. huidobrensis (Blanchard), and L. langei. The predominant species in the major lettuce production areas in central California was believed to be L. huidobrensis (pea leafminer) until recently (Morgan et al., 2000). Scheffer and co-workers (2001) identified the leafminers in central California to be the morphologically cryptic species $L$. langei by using polymerase chain reaction (PCR) amplification of mitochondrial DNA. Adult sting and larval mining of leaves by leafminer reduce photosynthetic capacity, render lettuce leaves unmarketable, and provide an entrance for disease organisms (Univ. of California, 1992).

Limited studies on leafminer resistance in vegetables have been reported. Larval (L. trifolii) antibiosis was found in four interspecific hybrids of Lycopersicon pennellii, L. cheesmanii, and L. hirsutum, and adult antibiosis and antixenosis for feeding was partially a result of the tomato plant's trichome exudates (Erb et al., 1993). No resistance to leafminers (L. trifolii) has been observed in cultivated celery, but an accession of a wild species, Apium prostratum, was found to be practically immune as no feeding or oviposition

Received for publication 10 July 2002. Accepted for publication: 10 Nov. 2002. We would like to thank William E. Chaney and Franklin K. Dlott for their technical advice, and James D. McCreight and Ravindra G. Bhat for their critical review and discussion of the manuscript. This research was supported in part by a grant from the California Lettuce Research Board.

${ }^{1}$ Research Geneticist. To whom reprint requests should be addressed. E-mail address: bmou@pw.ars.usda.gov

${ }^{2}$ Research Entomologist. was observed (Trumble and Quiros, 1988). The accession has been used in a backcross program in an attempt to develop leafminerresistant celery lines (Quiros, 1993). An accession from another wild species, A. nodiflorum, demonstrated substantial insect toxicity; few mines were observed and no larvae survived to the pupal stage (Trumble et al., 1990). In lettuce, female leafminers (L.trifolii) survived significantly longer and produced more stings and pupae on the cultivar Tall Guzmaine than on three other cultivars (Nagata et al., 1998; Nuessly and Nagata, 1994).

Genetic variation of leafminer resistance in lettuce germplasm, including the wild species, has not been fully explored. The purposes of the present study were to evaluate differences in lettuce genotypes to leafminer damage and to estimate the heritabilities of leafminer resistance in lettuce.

\section{Materials and Methods}

Experiments were conducted at the Agricultural Research Station of the U.S. Dept. of Agriculture, Salinas, Calif., in 2001. Forty-six genotypes from the lettuce germplasm collection maintained at the station were used in this study. They include crisphead, leaf, romaine, butterhead, stem, Latin, Batavia, and primitive forms of cultivated lettuce (L. sativa), and the wild species L. serriola, L. saligna, and $L$. virosa from different geographic areas of the world.

Seeds of each genotype were planted in plastic pots $(10 \times 10 \times 10 \mathrm{~cm})$ containing a mixture of 2 sand : 1 soil (by volume) in greenhouse. Four weeks after planting, 12 plants of each genotype were transplanted individually into plastic pots $(10 \times 10 \times 10$ $\mathrm{cm}$ ) with field soil. Six plants of each lettuce line were used in an initial test 3 weeks after transplanting and the other six plants of each genotype were used in a second test 5 weeks after transplanting. In each test, plants were placed in a field cage $(2 \mathrm{~m}$ high $\times 4 \mathrm{~m}$ wide $\times$ $4 \mathrm{~m}$ deep) covered with polypropylene fabric and were arranged in a randomized complete block with a single plant as the experimental unit and six replications.

Lettuce leaves with leafminer mines were collected from newly harvested fields around Salinas and hung in shade to allow leafminer larvae to emerge from the leaves and pupate. Pupae were collected, weighed, and put in plastic containers to allow the adult flies to emerge. Weight of a random sample of 200 pupae was used to estimate number of pupae collected. Sampled pupae were reared to adults to determine percentage of viable pupae. Total number of flies was estimated based on weight and emergence of sampled pupae. In the first test, $\approx 3500$ flies were released in the field cage, and in the second test 2500 flies were released. Number of leafminer stings was counted in a $20-\mathrm{cm}^{2}$ leaf area with the highest sting density on each plant with the aid of an optical glass binocular magnifier (OptiVisor, Donegan Optical Co., Lenexa, Kans.) 7 d after the introduction of leafminer flies in the cage. The date when mines first appeared on each plant was recorded. Each plant was then put into a 7.6-L plastic pot covered with polypropylene fabric before larvae emerged from leaves. A yellow sticky card was taped on the inside surface of the pot to catch emerging adult flies. Number of flies on each card was counted 6 weeks later. Only the number of stings per $20-\mathrm{cm}^{2}$ leaf area was counted in the second test.

The period from release of flies in the cage to first appearance of a mine on a plant is defined as the egg-hatching period. Data were analyzed statistically by using the analysis of variance (ANOVA) functions of the Microsoft Excel (Microsoft Office 2001, Microsoft Co., Redmond, Wash.). Means of different lettuce types were compared by constructing contrasts with $F$ tests (Petersen, 1985). Broad-sense heritability $\left(h^{2}\right)$ was estimated from the components of variances (Singh and Chaudhary, 1977):

$$
h^{2}=\sigma_{\mathrm{g}}^{2} /\left(\sigma_{\mathrm{g}}^{2}+\sigma_{\mathrm{e}}^{2}\right)
$$

where $\sigma_{\mathrm{g}}^{2}$ is genotypic variance and $\sigma_{\mathrm{e}}^{2}$ is environmental variance. Since the genotypes used in this study are autogamous and genetically uniform, the expected mean squares for error will be a random environmental variance.

\section{Results and Discussion}

Significant genotypic differences were found for traits measured (Table 1). Number of leafminer stings per $20-\mathrm{cm}^{2}$ leaf area ranged from 18.7 to 433.7 in Test 1 and from 1.7 to 205.0 in Test 2 (Table 2). Egg-hatching period varied from 6.5 to $12.3 \mathrm{~d}$. Number of flies emerged from each plant differed from 0.0 to 5.5. These results suggest that lettuce genotypes differ in their suitability as leafminer hosts, and resistance to leafminers exists in lettuce germplasm.

PI509525(L.saligna) had fewest leafminer stings among genotypes in both tests (Table 2 ). 
Although it had a few mines in two replications, no flies emerged from them. Among the cultivated lettuces (L. sativa), PI 187238, PI 491212, 'Bologna', 'Alpi', PI 342534, 'Lolla Rossa', 'Cosberg', 'Red Grenoble', PI491225, and 'Batavia Lydia' showed fewer leafminer stings per unit leaf area than other lines. 'Lolla Rossa' also had longest egg-hatching period, suggesting that its leaves may impede progress of this developmental stage. 'Da Ye Wo Sun', a stem lettuce from China, registered the most sting damage among genotypes tested. It also had a short egg-hatching period and the most flies per plant, making it a suitable host for leafminers. These results demonstrate the existence of high levels of leafminer resistance in different lettuce types and species. None of the 46 genotypes tested was immune to leafminer. All genotypes had at least a few stings and leafminer adults emerged from all genotypes except PI 509525.

When different types of lettuce were compared, wild species (L. serriola, L. saligna, and L. virosa) had significantly fewer leafminer stings than cultivated lettuce in both tests (Tables 1 and 3). Leaf (leaf and romaine) type of lettuce also showed significantly fewer stings than the head (crisphead and butterhead) types, while the differences between leaf and romaine lettuces, and between crisphead and butterhead types were nonsignificant. None of the comparisons for hatching period or number of flies per plant was significant. These results suggest that head lettuce types are generally more susceptible to leafminer stings than the leaf types. Although wild species usually have fewer leafminer stings than cultivated lettuce, transfer of resistance from wild species often brings in horticulturally undesirable traits. It may be easier to use the cultivated lettuce as source of resistance in a breeding program. However, genes from wild species can be used to broaden the genetic base of resistance.

In these choice tests, fewer stings per unit leaf area suggest host nonpreference (antixenotic resistance). Longer hatching period could be due to antibiotic effect, while either antixenosis or antibiosis, or both may cause fewer flies per plant. Resistance based on antixenosis would be desirable because even the photosynthetic losses caused by adult feeding and oviposition would be reduced (Trumble et al., 1985). It could prompt leafminer movements to weeds or crops tolerant to insect damage. For example, broccoli or cauliflower (Brassica sp.) (both important crops in central California) with six or more leaves are rarely damaged by leafminers, regardless of population numbers (Univ. of California, 1992).

Heritability estimates for number of stings per unit leaf area were consistent from the two tests $(64.8 \pm 5.7 \%$ [standard error (SE)] and 65.2 $\pm 5.7 \%$ ). Heritabilities for egg-hatching period and number of flies per plant were much lower, at $10.1 \pm 5.3 \%$ and $14.6 \pm 5.7 \%$, respectively. Broad-sense heritability measures the portion of variation observed for a trait that is due to genetic or heritable cause, as opposed to environmental influence. It suggests that number of stings per unit leaf area is a more reliable trait in selecting leafminer-resistant plants.
Table 1. Mean squares and selected contrasts from analysis of variance (ANOVA) of stings per $20-\mathrm{cm}^{2}$ leaf area, egg-hatching period (days), and number of flies per plant for 46 lettuce genotypes.

\begin{tabular}{lrcccc}
\hline & & \multicolumn{4}{c}{ Mean squares } \\
\cline { 3 - 5 } & & \multicolumn{3}{c}{ Test 1 } & Test 2 \\
\cline { 3 - 5 } Source & df $^{z}$ & Stings & Hatching & Flies & Stings \\
\hline Block & 5 & $12275.6^{*}$ & $42.3^{* *}$ & $20.3^{* *}$ & $2676.4^{* *}$ \\
Genotype & 45 & $51130.4^{* *}$ & $9.7^{* *}$ & $6.9^{* *}$ & $9021.7^{* *}$ \\
$\quad$ Wild & 1 & $346363.7^{* *}$ & 0.8 & 5.8 & $73069.7^{* *}$ \\
$\quad$ Leaf \& cultivated & 1 & $90600.6^{* *}$ & 10.2 & 0.0 & $5123.0^{* *}$ \\
$\quad$ Leaf vs. romaine vs. head & 1 & 2727.5 & 2.4 & 1.4 & 1331.7 \\
$\quad$ Butterhead vs. crisphead & 1 & 7148.5 & 9.3 & 1.7 & 1165.0 \\
Error & 225 & 4239.9 & 5.8 & 3.4 & 736.2 \\
\hline
\end{tabular}

${ }^{2}$ Degree of freedom (df) of genotype and error are 43 and 215, respectively, for hatching, as PI 509525 and 'Red Grenoble' had egg hatching in only two and one replications, respectively, and were excluded from the ANOVA.

yild species: L. serriola, L. saligna, and L. virosa.

${ }^{x}$ Head types include butterhead and crisphead lettuces.

${ }^{*, * *} F$ tests significant at the $5 \%$ and $1 \%$ level, respectively.

Table 2. Means and least significant differences (LSD) at $P=0.05$ for number of stings per $20-\mathrm{cm}^{2}$ leaf area, egg-hatching period (days), and number of flies per plant for 46 lettuce genotypes.

\begin{tabular}{|c|c|c|c|c|c|}
\hline \multirow[b]{2}{*}{ Genotype } & \multirow[b]{2}{*}{ Species, type } & \multicolumn{3}{|c|}{ Test 1} & \multirow{2}{*}{$\begin{array}{l}\text { Test } 2 \\
\text { stings }\end{array}$} \\
\hline & & Stings & Hatching & $\overline{\text { Flies }}$ & \\
\hline PI 509525 & L. saligna & 18.7 & $6.5^{z}$ & 0.0 & 1.7 \\
\hline PI 187238 & L. sativa, leaf & 29.2 & 7.3 & 2.2 & 10.3 \\
\hline PI 274901 & L. serriola & 44.0 & 9.8 & 1.7 & 36.8 \\
\hline PI 274375 & L. virosa & 46.7 & 8.2 & 1.0 & 17.7 \\
\hline PI 491178 & L. serriola & 50.7 & 10.0 & 1.8 & 10.2 \\
\hline PI 491212 & L. sativa, romaine & 53.3 & 9.2 & 3.0 & 11.3 \\
\hline Bologna & L. sativa, leaf & 63.7 & 10.5 & 2.3 & 32.5 \\
\hline Alpi & L. sativa, romaine & 66.3 & 10.8 & 2.3 & 38.0 \\
\hline PI 342534 & L. sativa, butterhead & 66.8 & 7.8 & 1.5 & 43.0 \\
\hline Lolla Rossa & L. sativa, leaf & 69.3 & 12.3 & 4.0 & 26.2 \\
\hline Cosberg & L.sativa, crisphead & 70.8 & 8.3 & 2.8 & 27.8 \\
\hline Red Grenoble & L. sativa, leaf & 71.2 & $11.0^{y}$ & 0.5 & 25.2 \\
\hline PI 491225 & L. sativa, romaine & 73.3 & 7.5 & 1.5 & 49.7 \\
\hline Batavia Lydia & L. sativa, Batavia & 74.8 & 7.0 & 1.7 & 37.3 \\
\hline PI 212099 & L. sativa, leaf & 77.0 & 7.8 & 2.3 & 70.5 \\
\hline PI 490999 & L. saligna & 79.2 & 7.7 & 4.2 & 5.2 \\
\hline Okayama & L. sativa, butterhead & 96.7 & 9.3 & 1.5 & 65.3 \\
\hline PI 323940 & L. sativa, leaf & 99.7 & 8.5 & 3.7 & 62.7 \\
\hline PI 288244a & L. sativa, Latin & 99.8 & 8.3 & 2.7 & 51.2 \\
\hline Dark Green Boston & L. sativa, butterhead & 100.0 & 9.0 & 1.5 & 42.2 \\
\hline PI 255568 & L. sativa, Batavia & 107.2 & 7.7 & 2.5 & 100.8 \\
\hline Syreka & L. sativa, leaf & 120.7 & 8.3 & 1.3 & 31.7 \\
\hline Jade & L. sativa, crisphead & 126.8 & 8.0 & 3.7 & 69.0 \\
\hline PI 251247 & L. sativa, primitive & 129.2 & 10.2 & 1.0 & 56.7 \\
\hline PI 358003 & L. sativa, butterhead & 131.8 & 9.7 & 1.5 & 69.3 \\
\hline La Brillante & L. sativa, romaine & 149.0 & 9.8 & 2.5 & 64.0 \\
\hline Salinas & L. sativa, crisphead & 152.7 & 9.2 & 1.7 & 68.0 \\
\hline King Crown & L. sativa, crisphead & 158.3 & 9.2 & 2.0 & 95.2 \\
\hline Cerise & L. sativa, leaf & 163.8 & 11.0 & 3.0 & 63.0 \\
\hline Bibb & L. sativa, butterhead & 177.2 & 11.2 & 2.5 & 63.3 \\
\hline Paris White & L. sativa, butterhead & 194.0 & 9.7 & 2.0 & 66.2 \\
\hline PI 491014 & L. sativa, Latin & 204.3 & 10.3 & 1.5 & 35.3 \\
\hline Donia & L. sativa, butterhead & 214.7 & 10.2 & 2.2 & 44.7 \\
\hline PI 358038c & L. sativa, crisphead & 216.0 & 9.8 & 0.8 & 80.0 \\
\hline Achat & L. sativa, butterhead & 217.0 & 8.2 & 2.5 & 42.7 \\
\hline PI 507930 & L. sativa, crisphead & 226.3 & 9.7 & 2.3 & 69.8 \\
\hline Deer's Tongue & L. sativa, leaf & 239.0 & 7.8 & 3.2 & 93.8 \\
\hline Lobjoits & L. sativa, romaine & 239.8 & 10.7 & 1.7 & 114.7 \\
\hline Dark Green Cos & L. sativa, romaine & 244.8 & 9.8 & 1.8 & 87.0 \\
\hline Calrico & L. sativa, crisphead & 249.7 & 6.5 & 4.3 & 81.3 \\
\hline Acefield & L. sativa, crisphead & 259.8 & 8.5 & 1.8 & 66.8 \\
\hline PI 491006 & L. sativa, primitive & 266.3 & 9.3 & 2.3 & 102.2 \\
\hline Iceberg & L. sativa, Batavia & 267.0 & 10.0 & 3.3 & 121.7 \\
\hline Margarita & L. sativa, butterhead & 293.8 & 8.2 & 4.3 & 130.0 \\
\hline Royal Oak Leaf & L. sativa, leaf & 333.8 & 10.2 & 1.3 & 115.0 \\
\hline Da Ye Wo Sun & L. sativa, stem & 433.7 & 7.8 & 5.5 & 205.0 \\
\hline $\mathrm{LSD}_{0.05}$ & & 74.1 & 2.7 & 2.1 & 30.9 \\
\hline
\end{tabular}

${ }^{2}$ Data from the only two replications that showed egg hatching.

yata from the only replication that showed egg hatching. 
Table 3. Means of stings per $20-\mathrm{cm}^{2}$ leaf area, egg-hatching period (days), and number of flies per plant by lettuce type.

\begin{tabular}{lrcccc}
\hline & & \multicolumn{3}{c}{ Test 1} & $\begin{array}{c}\text { Test 2 } \\
\text { Lettuce type }\end{array}$ \\
\cline { 3 - 4 } & $\mathrm{n}^{\mathrm{z}}$ & Stings & Hatching & Flies & stings \\
\hline Wild species & 5 & 47.9 & 8.9 & 1.7 & 14.3 \\
Leaf & 10 & 126.7 & 9.3 & 2.4 & 53.1 \\
Romaine & 6 & 137.8 & 9.6 & 2.1 & 60.8 \\
Butterhead & 9 & 165.8 & 9.3 & 2.2 & 63.0 \\
Crisphead & 8 & 182.6 & 8.7 & 2.4 & 69.7 \\
Batavia & 3 & 149.7 & 8.2 & 2.5 & 86.6 \\
Latin & 2 & 152.1 & 9.3 & 2.1 & 43.3 \\
Primitive & 2 & 197.8 & 9.8 & 1.7 & 79.5 \\
Stem & 1 & 433.7 & 7.8 & 5.5 & 205.0 \\
\hline
\end{tabular}

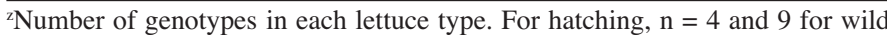
species and leaf lettuce, respectively.

Plants in Test 2 were 2 weeks older than the plants in Test 1 . They were also subjected to different leafminer pressures. More flies were introduced in Test 1 , resulting in higher densities of leafminer stipples. Nevertheless, results of the stings per unit leaf area from the two tests were highly correlated $(r=0.828)$. The consistency in performance demonstrated that differences in resistance were stable over different plant ages and against different pressures of leafminer.

Chemical control of leafminers usually lasts only a short period of time. Adult control with contact insecticides is especially unsatisfactory because the flies can easily move around, and the treated field is subject to reinfestation from adjacent untreated crops and weeds (LeStrange et al., 1999). Many studies have shown that leafminers can develop a high degree of resistance to a broad range of insecticides (Keil and Parrella, 1990; Mason et al., 1987; Parrella and Trumble, 1989). Therefore, it is essential to develop alternative management strategies for leafminers.

Resistant varieties remain the most economical means of insect control. Their use cuts down the costs of chemicals, machinery, fuel, and labor associated with pesticide spray. It also reduces workers' exposure to hazardous chemicals. Insecticide residues in the plants may be reduced, resulting in increased consumer acceptance of lettuce product. It may J. Econ. Entomol. 83:18-26. also reduce pesticide contamination of soil and ground water, alleviating the pressure on the environment. Lettuce products free from leafminer stings and mines have potentially greater quality, marketability, and value.

In our study, a wide range of genetic variability was found in different types and species of lettuce. Coupled with the relatively high heritability estimates for number of stings per unit leaf area and the stability of the trait, genetic improvement of lettuce for leafminer resistance seems feasible. We are currently incorporating the resistant sources found in this study into elite cultivars in a lettuce breeding program.

\section{Literature Cited}

Erb, W.A., R.K. Lindquist, N.J. Flickinger, and M.L. Casey. 1993. Resistance of selected interspecific Lycopersicon hybrids to Liriomyza trifolii (Diptera:Agromyzidae). J. Econ. Entomol. 86: 100-109.

Keil, C.B. and M.P. Parrella. 1990. Characterization of insecticide resistance in two colonies of Liriomyza trifolii (Diptera: Agromyzidae).

LeStrange, M., S. Koike, J. Valencia, and W. Chaney. 1999. Spinach production in California. Univ. of California, Div. of Agr. and Natural Resources, Publ. 7212. p. 3-4.

Mason, G.A., M.W. Johnson, and B.E. Tabashnik. 1987. Susceptibility of Liriomyza sativae and Liriomyza trifolii (Diptera:Agromyzidae) to permethrin and fenvalerate. J. Econ. Entomol. 80:1262-1266.

Morgan, D.J.W., S.R. Reitz, P.W. Atkinson, and J.T. Trumble. 2000. The resolution of Californian populations of Liriomyza huidobrensis and Liriomyza trifolii (Diptera: Agromyzidae) using PCR. Heredity 85:53-61.

Nagata, R.T., L.M. Wilkinson, and G.S. Nuessly. 1998. Longevity, fecundity, and leaf stippling of Liriomyza trifolii (Diptera: Agromyzidae) as affected by lettuce cultivar and supplemental feeding. J. Econ. Entomol. 91:999-1004.

Nuessly, G.S. and R.T. Nagata. 1994. Differential probing response of Serpentine leafminer, Liriomyza trifolii (Burgess), on cos lettuce. J. Entomol. Sci. 29:330-338.

Parrella, M.P. 1987. Biology of Liriomyza. Annu. Rev. Entomol. 32:201-224.

Parrella, M.P. and J.T. Trumble. 1989. Decline of resistance in Liriomyza trifolii (Diptera: Agromyzidae) in the absence of insecticide selection pressure. J. Econ. Entomol. 82:365-368.

Petersen, R. G. 1985. Design and analysis of experiments. Marcel Dekker, New York. p. 85-111.

Quiros, C.F. 1993. Celery breeding program at the Department of Vegetable Crops, University of California, Davis. HortScience 28:250.

Scheffer, S.J., A. Wijesekara, D. Visser, and R.H. Hallett. 2001. Polymerase chain reaction-restriction fragment-length polymorphism method to distinguish Liriomyza huidobrensis from $L$. langei (Diptera: Agromyzidae) applied to three recent leafminer invasions. J. Econ. Entomol. 94:1177-1182.

Singh, R.K. and B.D. Chaudhary. 1977. Biometrical methods in quantitative genetic analysis. Kalyani Publishers, New Delhi, India. p. 52-54.

Trumble, J.T., W. Dercks, C.F. Quiros, and R.C. Beier. 1990. Host plant resistance and linear furanocoumarin content of Apium accessions. J. Econ. Entomol. 83:519-525.

Trumble, J.T. and C.F. Quiros. 1988. Antixenotic and antibiotic resistance in Apium species to Liriomyza trifolii (Diptera: Agromyzidae). J. Econ. Entomol. 81:602-607.

Trumble, J.T., I. Ting, and L. Bates. 1985. Analysis of physiological, growth, and yield responses of celery to Liriomyza trifolii. Entomol. Exp. Appl. 38:15-21.

University of California. 1992. Integrated pest management for cole crops and lettuce. Statewide Integrated Pest Management Project, Div. of Agr. and Natural Resources, Publ. 3307, p. 31-32. 